\title{
Local-scale impact of wind energy farms on rare, endemic, and threatened plant species
}

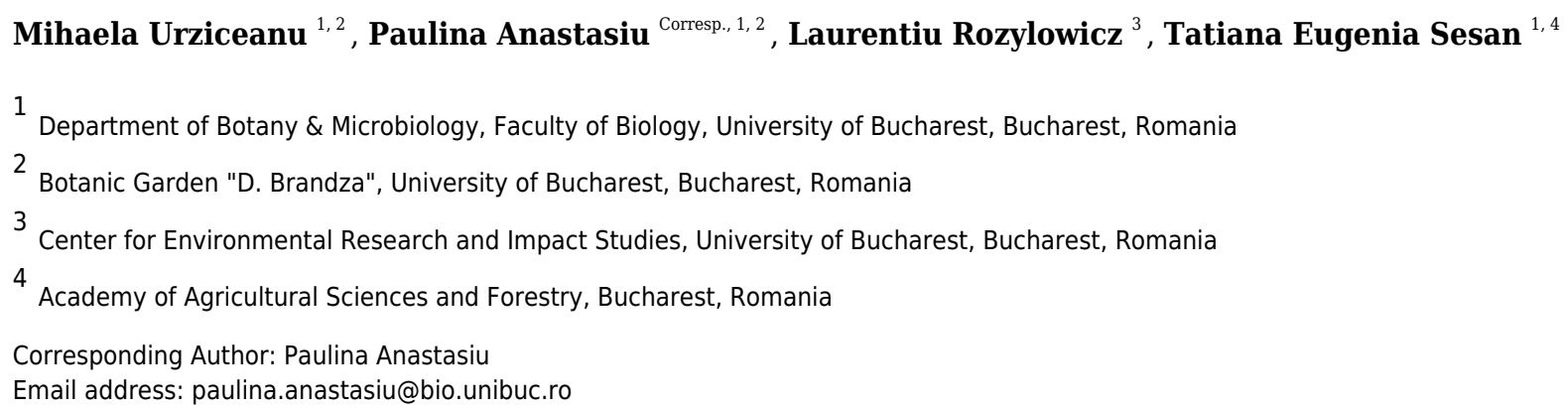

Background. Wind energy farms have become a popular solution to produce green energy worldwide. Their development within protected areas has increased dramatically in the past decade, and the effects on as rare, endemic and threatened plant species (i.e., protected plant species), essential for habitat conservation and management, are little known. Only few studies directly quantify the impacts of wind energy farms on them. Our study analyzes the effect of wind energy farms on rare, endemic, and threatened plant species in steppic habitats and their recovery potential over a ten-year period on a wind farm within the Dealurile Agighiolului Natura 2000 site (Dobrogea Region, SE Romania). Methods. We surveyed the rare, endemic, and threatened plant species within a radius of approximately $50 \mathrm{~m}$ around each of the 17 wind towers during the wind farm's operational phase. We selected 34 plots to allow the investigation of two types of areas: 1) a disturbed area overlapping the technological platform, where the vegetation was removed before construction, and 2) an adjacent undisturbed area. To understand the effects of the wind energy farm on the rare, endemic, and threatened plant species diversity and the differences between the disturbed and undisturbed areas, we calculated under both conditions: 1) plant species richness; 2) sample-size-based rarefaction and extrapolation with Hill numbers parameterized by species richness; 3) non-metric multidimensional scaling of Jaccard dissimilarity index; 4) functional diversity; 5) beta-diversity (including replacement and nestedness of species). Results. As a result of the disturbances caused by the wind energy farm's development, we identified a sharp contrast between the diversity of rare, endemic, and threatened plants inhabiting disturbed and undisturbed areas near the wind towers. Our research showed that less than $40 \%$ of the total inventoried rare, endemic, and threatened species colonized the disturbed sites. Species turnover within undisturbed plots was higher than disturbed plots, implying that the plant 
community's heterogeneity was high. However, a higher richness in rare, endemic, and threatened plant species was found in the plots around the wind towers in grasslands of primary type. Sample-size-based rarefaction and extrapolation with Hill numbers by observed species richness indicated an accurate estimation of species richness in disturbed habitats, demonstrating that recovery after wind energy farm construction was incomplete after ten years of low-intensity plant restoration and conservation activities. Thus, we consider that operating activities must be reconfigured to allow the complete recovery of the communities with rare, endemic, and threatened plant species. 


\section{Local-scale impact of wind energy farms on rare, 2 endemic, and threatened plant species}

3 Mihaela Urziceanu ${ }^{1,2}$, Paulina Anastasiu ${ }^{1,2}$, Laurentiu Rozylowicz ${ }^{3}$, Tatiana Eugenia Sesan ${ }^{1,4}$ 4

$5{ }^{1}$ Department of Botany \& Microbiology, Faculty of Biology, University of Bucharest, 6 Bucharest, Romania

$7 \quad 2$ Botanic Garden "D. Brandza", University of Bucharest, Bucharest, Romania

$8{ }^{3}$ Center for Environmental Research and Impact Studies, University of Bucharest, Bucharest, 9 Romania

$10{ }^{4}$ Academy of Agricultural Sciences and Forestry, Bucharest, Romania 11

12 Corresponding Author:

13 Paulina Anastasiu ${ }^{1,2}$

14 Intrarea Portocalelor 1-3, Bucharest, 060101, Romania

15 Soseaua Cotroceni 32, Bucharest, 060114, Romania

16 Email address: paulina.anastasiu@bio.unibuc.ro; anastasiup@yahoo.com. 


\section{Abstract}

18 Background. Wind energy farms have become a popular solution to produce green energy

19

20

21

22

23

24

25

26

27

28

29

30

31

32

33

34

35

36

37

38

39

40

41

42

43

44

45

46

47

48

49

\section{0}

51

52

53

54

55

56

worldwide. Their development within protected areas has increased dramatically in the past decade, and the effects on as rare, endemic and threatened plant species (i.e., protected plant species), essential for habitat conservation and management, are little known. Only few studies directly quantify the impacts of wind energy farms on them. Our study analyzes the effect of wind energy farms on rare, endemic, and threatened plant species in steppic habitats and their recovery potential over a ten-year period on a wind farm within the Dealurile Agighiolului Natura 2000 site (Dobrogea Region, SE Romania).

Methods. We surveyed the rare, endemic, and threatened plant species within a radius of approximately $50 \mathrm{~m}$ around each of the 17 wind towers during the wind farm's operational phase. We selected 34 plots to allow the investigation of two types of areas: 1) a disturbed area overlapping the technological platform, where the vegetation was removed before construction, and 2) an adjacent undisturbed area. To understand the effects of the wind energy farm on the rare, endemic, and threatened plant species diversity and the differences between the disturbed and undisturbed areas, we calculated under both conditions: 1) plant species richness; 2) samplesize-based rarefaction and extrapolation with Hill numbers parameterized by species richness; 3 ) non-metric multidimensional scaling of Jaccard dissimilarity index; 4) functional diversity; 5) beta-diversity (including replacement and nestedness of species).

Results. As a result of the disturbances caused by the wind energy farm's development, we identified a sharp contrast between the diversity of rare, endemic, and threatened plants inhabiting disturbed and undisturbed areas near the wind towers. Our research showed that less than $40 \%$ of the total inventoried rare, endemic, and threatened species colonized the disturbed sites. Species turnover within undisturbed plots was higher than disturbed plots, implying that the plant community's heterogeneity was high. However, a higher richness in rare, endemic, and threatened plant species was found in the plots around the wind towers in grasslands of primary type. Sample-size-based rarefaction and extrapolation with Hill numbers by observed species richness indicated an accurate estimation of species richness in disturbed habitats, demonstrating that recovery after wind energy farm construction was incomplete after ten years of low-intensity plant restoration and conservation activities. Thus, we consider that operating activities must be reconfigured to allow the complete recovery of the communities with rare, endemic, and threatened plant species.

\section{Introduction}

Plants are a vital component of biodiversity and play a key role in maintaining ecosystems' ecological stability, e.g., by providing irreplaceable ecosystem services $(C B D, 2012)$. Human society depends on economic growth, and the depletion of resources dramatically transforms the environment, driving species towards extinction at an unprecedented rate in human history (Corlett, 2016; Johnson et al., 2017; Meng et al., 2019). Plant species are exposed to higher extinction risk due to habitat loss and fragmentation, competition with invasive species, and 
57 climate change effects, yet available plant conservation initiatives are overlooked compared with

58

59

60

61

62

63

64

65

66

67

68

69

70

71

72

73

74

75

76

77

78

79

80

81

82

83

84

85

86

87

88

89

90

91

92

93

94

95

96

wildlife conservation (Mouillot et al., 2013; Corlett, 2016; Zambrano et al., 2018).

The establishment of protected areas is a major tool for conserving biodiversity worldwide (Miu et al., 2020). Protected areas were created to safeguard biodiversity, more so of rare, endemic, and threatened plant species, but are presently facing pressures such as a dense transport infrastructure, over-tourism, intensive agriculture, habitat transformation, and altered hydrological and fire regimes (Schulze et al., 2018). The development of infrastructure for renewable energy production is regarded as a threat to protected areas; moreover, wind energy farms can significantly impact biota where large-scale systems are developed (Schulze et al., 2018). Threats to biota from wind energy farm development typically include increased mortality of birds and bats, alteration of habitats and landscapes, and increased noise (Kuvlesky et al., 2007; Katsaprakakis, 2012; Gasparatos et al., 2017; Măntoiu et al., 2020), while immediate and long-term effects on plant species are less studied (Silva \& Passos, 2017, Nita, 2019). However, research on the impact of wind energy farms on plant species is gaining traction. Several studies have demonstrated a reduced diversity of plant species close to wind energy farms and the displacement of rare, endemic, or threatened plants by temporary ruderal and invasive species (Fraga et al., 2008; Renou-Wilson \& Farell, 2009; Passos et al., 2013; Silva \& Passos, 2017; Keehn \& Feldman, 2018). For example, Keehn and Feldman (2018) indicated that plant communities disturbed by wind energy farms in Southern California (USA) are less abundant and diversified in endemic plants than areas without wind energy farms. In Europe, several studies focusing on the impact of wind energy farms on mires and peat habitats suggest that the diversity of plant species is diminished in disturbed habitats and that their impact is particularly prominent on rare and threatened plant species (Dargie, 2004; Fraga et al., 2008; Fagúndez, 2008; Renou-Wilson \& Farell, 2009; Natural England, 2010).

Furthermore, several studies indicated that during operation, wind farms might affect the local climate (temperature and rainfall) (Zhou et al., 2012; Tang et al., 2017), resulting in an additional stress factor for vegetation growth. Xu et al. (2019) observed positive ecological effects of wind farms' operational phase in the Gobi Desert, China. Nearby wind towers in desert areas, plants are less stressed, plant communities are denser, and have higher coverage than areas not occupied by wind towers. The positive effect might be due to the edge effect of areas cleared of vegetation, as well as the fact that rainwater flows along the roads and the ditches of underground power lines providing more water for vegetation, making it more diverse, more productive, and more stable (Xu et al., 2019).

Owing to the multiplicity of continental and marine climatic influences, the Dobrogea region (SE Romania) is the most diverse area of the Steppic European Biogeographical Region (Rozylowicz et al., 2019). Dobrogea is regarded as a biodiversity hotspot, with a high diversity of species protected at the national or European level (Sârbu et al., 2006; Georgescu et al., 2015; Miu et al., 2018; Miu et al., 2020). Over 63\% (i.e., 9,700 $\mathrm{km}^{2}$ ) of the Dobrogea region is part of the European Natura 2000 network, either as special protection areas (SPAs, established under the Birds Directive) or Sites of Community Importance (SCIs, established under the Habitats

PeerJ reviewing PDF | (2020:12:56079:1:0:NEW 20 Feb 2021) 
97 Directive) (Miu et al., 2018). Despite the very good coverage of protected areas, the Dobrogea

98

99

100

101

102

103

104

105

106

107

108

109

110

111

112

113

114

115

116

117

118

119

120

121

122

123

124

125

126

127

128

129

130

131

132

133

134

135

136

region is impacted by various factors such as quarries, wind energy farms and solar energy facilities, development of transport infrastructure, logging, invasive or non-native species, overgrazing, and land transformation for agriculture (Petrescu, 2016). The high wind energy potential of the Dobrogea region (Dragomir et al., 2016), as well as substantial European Union subsidies for renewable energies, supported the construction of several wind energy farms, outside and within the protected natural areas (Doba et al., 2016). A total of 890 wind towers have been installed in Dobrogea, among which 142 are within Natura 2000 sites (Doba et al., 2016).

Even though Dobrogea has a considerable amount of wind towers in and out of protected areas, few published studies have investigated their impact on biodiversity. For instance, Măntoiu et al. (2020) demonstrated that even a minor wind energy farm of 20 wind towers could trigger high bat mortality in the absence of adequate conservation measures. To the best of our knowledge, the only study investigating the impact of wind energy towers on plant species biodiversity in Romania concluded that in the Mehedinți Mountains (SW Romania), there are no significant differences between grassland communities nearby wind towers and those situated $300 \mathrm{~m}$ away from towers (Pătru-Stupariu et al., 2019). However, the study was performed on a small-scale wind farm and did not capture plant communities from wind tower technological platforms. To contribute to a better understanding of the local-scale impact of wind energy farms on plant species susceptible to population size reductions and extinction, we analyzed the impact of wind energy farms on rare, endemic, and threatened plant species belonging to steppic grassland communities from the Natura 2000 site, Dealurile Agighiolului (Dobrogea, Romania), by contrasting the species diversity of disturbed and undisturbed plots near wind towers on Agighiol wind farm complex. We tested the hypothesis that disturbed areas (technological platforms) close to wind towers have a lower rare, endemic, and threatened plant species diversity than nearby undisturbed areas, indicating a significant local-scale impact of wind energy farms during the operational phase.

\section{Materials \& Methods}

\section{Study area}

Dobrogea is a geographically distinct region of $15,500 \mathrm{~km}^{2}$ located in Romania's southeastern part, between the Danube River and the Black Sea (Fig. 1). The climate is humid continental with hot-summers (Rey et al., 2007). Long-term climatic data indicate a mean annual temperature between 10.1 and $11.8^{\circ} \mathrm{C}$ and annual rainfall between 257.5 and $535.0 \mathrm{~mm}$ (Bandoc \& Prăvălie, 2015).

Dobrogea's vegetation includes over $35 \%$ of the total number of syntaxa (i.e., vegetation units) identified in Romania (Sanda \& Arcuş, 1999) and is the only Romanian region where steppe vegetation (Ponto-Sarmatic steppes) is still present (Petrescu, 2007). Steppes are rare in European Union countries and include endemic plant associations, such as Agropyro-Thymetum zygioidi, Pimpinello-Thymion zygioidi, and, Gymnospermio altaicae-Celtetum glabratae.

PeerJ reviewing PDF | (2020:12:56079:1:0:NEW 20 Feb 2021) 
137 Furthermore, Dobrogea hosts forest-steppe vegetation (grassland interspersed with areas of 138 Quercus pubescens, Carpinus orientalis, and Fraxinus ornus), coastal and halophilous 139 vegetation (mainly on the Black Sea coast and Danube Delta area), as well as reed swamps 140 (Scirpo-Phragmitetum and Thyphetum angustifoliae associations) and meadows in the Danube 141 Delta (where the Salix alba and Populus alba streams dominate) (Petrescu 2007).

142 The Natura 2000 site Dealurile Agighiolului (hereafter Dealurile Agighiolului) is located in the 143 northeastern part of Dobrogea, Romania (Fig. 1), in a hilly area covered by steppic grassland and 144 oak woodland surrounded by agricultural land (Brînzan, 2013). Dealurile Agighiolului was 145 designated as a Site of Community Importance (Natura 2000 code ROSCI0060) in 2007, with an 146 area of 1,433 ha. The site was designated for the conservation of three habitat types listed as having priority for conservation under Annex I of the Habitats Directive: Ponto-Sarmatic steppes (Natura 2000 code $62 \mathrm{C} 0^{*}$ ), Ponto-Sarmatic deciduous thickets (Natura 2000 code $40 \mathrm{C} 0^{*}$ ), and

150

151

152

153

154

155

156

157

158

159

160

161

162

163

164

165

166

167

168

169

170

171

172

173

174

175

176 Eastern white oak woods (Natura 2000 code $91 \mathrm{AA}^{*}$ ). These priority habitats encompass plant communities mainly distributed in the Dobrogea region, such as Koelerio lobatae-Thymetum zygioides and Paeonio peregrinae-Carpinetum orientalis (Chifu \& Țpu, 2009; Țupu, 2009; Brinzan, 2013). These communities harbor a significant number of protected plant species, such as the endemic Campanula romanica, restricted to Dobrogea, or regional species such as Alyssum caliacrae, Caragana frutex, Centaurea kanitziana, Convolvulus lineatus, Dianthus nardiformis, Hedysarum grandiflorum subsp. grandiflorum, Hornungia petraea, Paeonia peregrina, Paronychia cephalotes, Scorzonera mollis, Stachys angustifolia, Thymus zygioides, and Vincetoxicum fuscatum (Sârbu et al., 2007; Dihoru \& Negrean, 2009; Țupu, 2010; Petrescu, 2018).

Concerning the number of wind towers, the Agighiol wind farm is the second largest in a protected area in Dobrogea. The wind energy farm includes 17 Gamesa G87 2 MW wind towers, of which five are in the northeast CC_01 to CC_05 and 12 in the southeast DP_01 to DP_12 (Fig. 1). The area occupied by the tower pads and access roads is 5.45 hectares (Ministerul Mediului, Apelor şi Pădurilor, 2016).

All towers are built on priority habitat $62 \mathrm{C} 0 *$ Ponto-Sarmatic steppes, except for tower DP_03, which is surrounded by habitat $91 \mathrm{AA}^{*}$ Eastern white oak woods (Table 1, Fig. S1). Very close to towers CC_04 and DP_04, there are fragments of habitat 91AA*. The 62C0* habitat varies in terms of vegetation structure in the area of the wind farm. In areas where the influence of anthropogenic activity is low, there are plant associations typical for primary (natural) grasslands (e.g., Koelerio lobatae - Thymetum zygioides, Stipetum lessingianae). In intensely grazed areas or deforested areas, there are plant associations typical for secondary (semi-natural) grasslands (Artemisio austriacae-Poëtum bulbosae, Taraxaco serotini-Bothriochloëtum ischaemi) (Țup 2010; Petrescu, 2018).

\section{Data collection}

Between 2015 and 2019, we surveyed rare, endemic, and threatened plant communities around the 17 towers of the Agighiol wind energy farm. We performed six visits annually per plot from March to October. The surveyed area around each towers was within a radius of approximately 
$17750 \mathrm{~m}$ and included (1) a disturbed area, overlapping the technological platform, where the 178 vegetation was removed before construction (disturbed plots of $2,500 \mathrm{~m}^{2}$ each), and (2) the 179 undisturbed area, adjacent to the disturbed one, without interventions during the installation of 180 wind towers (undisturbed plots of 2,500 $\mathrm{m}^{2}$ each) (Fig. S1). The area of 2,500 $\mathrm{m}^{2}$ was chosen to 181 fit within a technological platform.

182 Romanian legislation mandates that all taxa included in national Red Lists be protected

183 (Guvernul României, 2007). Hence, surveyed plant taxa are considered protected if listed as rare, 184 endemic, or threatened in one of the following European or national regulations: Habitats 185 Directives (Council of the European Communities, 1992) on the conservation of natural habitats 186 and of wild fauna and flora, National Red Book (Dihoru \& Negrean, 2009) or the National Red 187 Lists (Oltean et al., 1994; Dihoru \& Dihoru, 1994; Boșcaiu et al., 1994).

188 The taxonomy considered in this paper follows the Euro+Med PlantBase

189 (http://ww2.bgbm.org/EuroPlusMed/, accessed on 9/07/2020) and Sârbu, Sttefan \& Oprea

190 (2013). The life forms, life span, and ecological indices are according to Sârbu, Ştefan, \& Oprea

191 (2013). Data on vegetative reproduction and seed dispersal are according to Dihoru \& Negrean

192 (2009).

\section{Analyses}

194 Data on protected plant taxa inventoried in the 34 investigated plots were stored for analyses in a 195 species by site incidence matrix (presence/absence) (Data S1). To evaluate protected plant

196

197

198

199

200

201

202

203

204

205

206

207

208

209

210

211

212

213

214

215

216 species diversity in disturbed and undisturbed plots by wind energy farm facilities, we calculated the species richness and compared the two investigated treatments using the Wilcoxon nonparametric test (Zar, 2010). Because the observed species richness is overly sensitive to sampling size and effort (Chao et al., 2014), we calculated the estimated species richness using sample-size-based rarefaction and extrapolation with Hill numbers $(q=0)$. The analysis was performed using the iNext R package (Hsieh et al., 2016). Hill numbers represent the effective number of species calculated as the number of equally abundant species necessary to produce the observed value of the analyzed diversity (Chao et al., 2014). By extrapolating the species richness to double or triple the minimum observed sample sizes, the analysis may show the difference between the two environments in terms of species richness (i.e., the magnitude of the differences in richness among communities) even when sample completeness is low (Hsieh et al., 2016).

To analyze how similar/dissimilar the investigated plots are, we used Non-metric Multidimensional Scaling (NMDS) of the Jaccard dissimilarity index in the vegan R package (Oksanen et al., 2019; $R$ Core Team, 2020). The approach produces a rank-based ordination of pairwise dissimilarity between sites and between species (i.e., objects) in a low-dimensional space (e.g., two dimensions). Two objects are more similar if they are ordinated closer together (e.g., two neighboring sites have more species in common). The number of plotted dimensions was determined using ordination stress. An ordination stress score lower than 0.2 indicates a good fit of the ordination plot, while a value close to zero indicates an outlier (site with an entirely different set of species). The ranks of the Jaccard dissimilarity distances were compared 
217 using analysis of similarity (ANOSIM) (Oksanen et al., 2019). We compared the mean of ranked

218 Jaccard dissimilarities between disturbed and undisturbed sites with the mean of ranked

219 dissimilarities within disturbed and undisturbed sites. If the ANOSIM statistic ( $R$-value) is close

220 to 1 (maximum), there is a high dissimilarity between the two groups, whereas a value close to -1

221 (minimum) indicates higher dissimilarities within groups than between disturbed and undisturbed

222 plots (Oksanen et al., 2019).

223 Furthermore, we analyzed trait diversity in the two compared environments utilizing the total

224 functional diversity metric available in the HillR package $(\mathrm{Li}, 2020)$. We used the following

225 relevant traits for our grassland community species: life span (annual, perennial), life form

226 (therophytes, hemicryptophytes, geophytes, and chamaephytes), vegetative reproduction (yes or

227 no), and seed dispersal (barochory, anemochory, zoochory, autochory, multiple) (Sârbu et al.

228 2013, Dihoru \& Negrean, 2009). Total functional diversity represents the effective total distance

229 between species of the analyzed environment and is similar to Functional Attribute Diversity

230 when using presence/absence data (Chiu \& Chao, 2014).

231 To investigate the biological processes contributing to the dissimilarity of the two compared

232 environments, replacement of species from one plot to another, or nested species losses, we

233 calculated beta diversity as Jaccard dissimilarity of all pairs of sites using the beta-pair function

234 of betapart in the R package (Baselga et al., 2020). The beta-pair function provides a monotonic

235 standardization of beta diversity (total dissimilarity) and two additive components: spatial

236 turnover dissimilarity (induced by replacement of species from one plot to another) and

237 nestedness-resultant dissimilarity (induced by nested species losses) (Baselga \& Laprieur, 2015).

238 The pairwise dissimilarities for each fraction of beta-diversity were tested for differences

239 between and within environments using Kruskal-Wallis non-parametric tests (Zar, 2010). We

240 tested for differences in Jaccard beta dissimilarities between the following groups: within

241 undisturbed plots (how dissimilar are undisturbed plots to each other), within disturbed plots

242 (how dissimilar are disturbed plots to each other), and between undisturbed and disturbed plots

243 (how dissimilar are disturbed plots when compared with undisturbed plots).

244 Graphs and statistics, other than beta diversity, functional diversity, NDSM, rarefaction, and

245 extrapolation, were produced using base and ggpubr R packages ( $R$ Core Team, 2020;

246 Kassambara, 2020). Maps were produced in ArcMap 10.4 (ESRI Redlands, CA, USA).

247

248 Results

249 We identified a total of 365 plant species around wind energy towers, of which 59 were

250 protected plant species (rare, endemic, or threatened). The number of protected species in the

251 disturbed plots was significantly lower than in the undisturbed plots (Wilcoxon rank-sum test $W$

$252=42.5, p<0.001$ ), i.e., 57 species in undisturbed plots and 24 species in disturbed plots (Data

253 S1). Moreover, the rank of plots in the disturbed areas by species richness was different from the

254 rank of paired plots in the undisturbed area (Wilcoxon signed-rank test $V=153, p<0.001$, Fig.

255 2). 
256 Sample-size-based rarefaction and extrapolation with Hill numbers parameterized by species 257 richness showed that the selected sampling units adequately captured the species diversity only 258 in disturbed plots (Fig. 3, Fig. S2). For example, if doubling the number of plots in both 259 treatments (e.g., from 17 to 34), the extrapolated species richness of the disturbed areas would be $26029.41(\mathrm{CI} 95 \%=22.04-36.82)$, a value close to the observed species richness, while the 261 extrapolated species richness of the undisturbed area would be $72.77(\mathrm{CI} 95 \%=60.11-85.43)$, 262 much higher than the observed species richness. Thus, the 17 surveyed plots in each treatment 263 captured $93.10 \%(\mathrm{CI} 95 \%=87.70-97.20)$ of the estimated number of species in undisturbed plots 264 and only $91.10 \%(C I 95 \%=88.10-94.20)$ in disturbed plots. If data are pooled together (total in 265 Fig. 3), the rarefaction and extrapolation analysis indicate sample completeness of $94.00 \%$ $266 \quad($ CI95\% $=91.70-96.20)$.

267 The most frequent plant species were Alyssum hirsutum and Thymus zygioides, present in 14 268 disturbed plots and 13 undisturbed plots (Fig. 4). Well represented in undisturbed plots, but to a 269 lesser extent in disturbed plots, were Muscari neglectum (10 undisturbed/ 9 disturbed), Koeleria 270 lobata (11 undisturbed/ 7 disturbed), Tanacetum millefolium (11 undisturbed/ 7 disturbed), 271 Bombycilaena erecta (10 undisturbed/ 6 disturbed), Echinops ritro subsp. ruthenicus (9 272 undisturbed/ 7 disturbed), Dianthus nardiformis (10 undisturbed/ 3 disturbed), Crocus 273 danubensis (9 undisturbed/ 0 disturbed), ) and Scorzonera mollis (9 undisturbed/ 0 disturbed) 274 (Fig. 4, Data S1). Three species had two occurrences, each being found in both types of plots 275 (Potentilla astracanica, Scutellaria orientalis var. pinnatifida, Seseli rigidum subsp. 276 peucedanifolium). A total of 21 plants had only one occurrence. Of these, 19 were observed in 277 undisturbed plots and two in disturbed plots, i.e., Allium guttatum, Allium saxatile, Astragalus 278 ponticus, Calepina irregularis, Campanula romanica, Carex brevicollis, Crocus pallasii, Cyanus 279 thirkei, Daucus guttatus subsp. zahariadii, Hedysarum grandiflorum subsp. grandiflorum, 280 Himantoglossum calcaratum subsp. jankae, Hornungia petraea, Iris sintenisii, Lathyrus cicera, 281 Onobrychis gracilis, Orchis simia, Ornithogalum amphibolum, Piptatherum virescens, and 282 Valerianella coronata, in undisturbed plots, and Hyoscyamus niger and Vicia peregrina, in 283 disturbed plots (Data S1).

284 Following the same pattern as species richness, total functional diversity was significantly lower 285 in disturbed plots than in undisturbed plots (Wilcoxon rank-sum test $W=221, p=0.002$, Fig. 286 S2).

287 Perennial plants dominated undisturbed plots and, to a lesser degree, disturbed plots (Fig. 5a). 288 Perennially protected plants in undisturbed plots were mostly hemicryptophytes and geophytes 289 (over 20 and 18 taxa, respectively), while chamaephytes were less represented (6 taxa) (Fig. 5a, 290 Data S1). Among perennial plants in disturbed plots, the most represented were 291 hemicryptophytes (nine taxa), followed by chamaephytes (five taxa) and geophytes (two taxa) 292 (Fig. 5a, Data S1).

293 Of the total of recorded protected species, 28 (47.45\%) were characterized by vegetative 294 reproduction, and only seven of them were also in the disturbed plots: Thymus zygioides, 
295

296

297

298

299

300

301

302

303

304

305

306

307

308

309

310

311

312

313

314

315

316

317

318

319

320

321

322

323

324

325

326

327

328

329

330

331

332

333

Muscari neglectum, Koeleria lobata, Tanacetum millefolium, Euphorbia myrsinites, Euphorbia nicaeensis subsp. dobrogensis, and Hyacinthella leucophaea (Fig. 5c, Data S1).

Analysis of seed dispersal traits showed a similar pattern in the investigated plots (Fig. 5d, Data S1). The most represented seed dispersal systems in both environments were multiple dispersal traits (e.g., barochory and zoochory, anemochory and zoochory, autochory and zoochory, and autochory and anemochory) and anemochory. Barochory and zoochory were less represented in disturbed plots, while zoochory is less represented in undisturbed plots. Autochory is rarely seen in species present in undisturbed plots and absent in disturbed plots (Fig. 5d).

The NMDS ordination of the investigated communities had a stress value of 0.174 . The first two dimensions of the ordination plots closely represent the community data. The NMDS ordination plot indicated a clear differentiation between disturbed and undisturbed plots (Fig. 6, Fig. S3). The ANOSIM test also indicated a significantly higher dissimilarity between environments than within environments $(R=0.25, p<0.001)$. Following NMDS ordination, most species had high specificity for one or the other two plot types; however, some species had a weak link with either one of these environments. These were mostly species observed only in one or two plots (e.g., in Fig. $6, \mathrm{SP} 52=$ Hyoscyamus niger, $\mathrm{SP} 33=$ Bupleurum apiculatum, $\mathrm{SP} 35=$ Galanthus plicatus, SP47 = Cyanus thirkei, $\mathrm{SP} 39=$ Seseli rigidum subsp. peucedanifolium, $\mathrm{SP} 40=$ Allium guttatum, SP44 = Campanula romanica, $\mathrm{SP} 59=$ Valerianella coronata, $\mathrm{SP} 43=$ Calepina irregularis, SP45 $=$ Carex brevicollis, $\mathrm{SP} 50=$ Himantoglossum calcaratum subsp. jankae, $\mathrm{SP} 53=$ Iris sintenisii, SP58 = Piptatherum virescens).

Beta diversity expressed as Jaccard dissimilarity for pairs of plots showed differences in the three compared situations: within undisturbed plots, within disturbed plots, and between undisturbed and disturbed plots (Kruskal Wallis rank-sum test $=21.92, d f=2, p<0.001$ ). Beta dissimilarity was significantly lower in disturbed plots than in the other two assemblages (Fig. 7a). The turnover component of beta diversity was similar in the three compared settings (Fig. 7b), while the nestedness-resultant was comparable in pairs of undisturbed and disturbed plots and higher when contrasting dissimilarity of undisturbed with disturbed plots (Fig. 7c). However, several pairs of disturbed and undisturbed plots had considerable nestedness-resultant dissimilarity (outliers in Fig. 7c).

\section{Discussion}

Our study indicates a significant negative local-scale impact of a wind energy farm on plant species diversity. By comparing rare, endemic, and threatened plant diversity from areas disturbed by wind towers (technological platforms and access roadsides) with nearby undisturbed areas, we detected a significantly lower alpha diversity and total beta dissimilarity of disturbed areas within the Dealurile Agighiolului. This sharp contrast is documented following ten years of the Agighiol wind energy farm's operational history, suggesting that routine wind farm maintenance without enforcing conservation measures hampered the colonization of areas disturbed during the construction phase. 
334 The number of protected species recorded in the investigated area was three times higher than in

335

336

337

338

339

340

341

342

343

344

345

346

347

348

349

350

351

352

353

354

355

356

357

358

359

360

361

362

363

364

365

366

367

368

369

370

371

372

373

the environmental impact assessment carried out prior to the construction of the wind farm (59 taxa versus 18 taxa) (Badea et al., 2012), suggesting that the ex-ante impact assessment failed to provide high-quality data to environmental authorities and wind farm operators. The lack of accuracy of environmental studies is a common issue (Nita et al., 2015), including when analyzing plant communities (Fraga et al., 2008; Passos, 2017).

Our extensive survey of plant communities surrounding the wind energy towers within Dealurile Agighioului indicates that less than $40 \%$ of the total inventoried protected plant species colonized the disturbed sites. The lower species richness observed in disturbed sites was also evident when compared to the undisturbed plots. None of the disturbed sites had a higher species alpha diversity than nearby undisturbed surveyed plots (Fig. 2). Most undisturbed plots hosted a much higher number of protected plant species than the disturbed plots. We found smaller differences between the number of species of disturbed and undisturbed sites for very few pairs of sites (CC_02, CC_03, and DP_07 wind towers). For wind energy towers located in secondary grassland, the number of inventoried protected species was low in the disturbed and undisturbed plots (i.e., CC_2, CC_3, DP_2), varying between 1 and 5 species. For wind energy towers located in primary grassland, the number of protected species was high (11 to 24 species). These results suggest a correlation between type of habitat surrounding each wind towers and the number of species from the adjacent disturbed area, plant communities near wind towers representing a pool of species for the impacted areas. However, the disturbance role of the wind farm in our area is also evident considering that the survey of disturbed habitats was almost complete (observed number of species $=24$, extrapolated number of species $=29$, Fig. 2). Sample-size-based rarefaction and extrapolation with Hill numbers indicated an accurate estimation of species richness in disturbed habitats (Fig. 3), supporting the conclusion that recovery after wind farm construction is far from complete even after ten years of maintenance activities. Of the 57 plant taxa present in undisturbed areas, only 22 taxa were also found in disturbed areas (e.g., Adonis flammea, Alyssum caliacrae, Alyssum hirsutum, Astragalus glaucus, Bombycilaena erecta, Centaurea kanitziana, Cerastium gracile, Dianthus nardiformis, Echinops ritro subsp. ruthenicus, Euphorbia myrsinites, Euphorbia nicaeensis subsp. dobrogensis, Hyacinthella leucophaea, Koeleria lobata, Minuartia adenotricha, Minuartia hybrida, Muscari neglectum, Potentilla astracanica, Scutellaria orientalis var. pinnatifida, Seseli rigidum subsp. peucedanifolium, Silene supina, Tanacetum millefolium, Thymus zygioides).

Trait diversity was significantly lower in disturbed areas than nearby undisturbed areas, suggesting that few traits may favor colonization of these impacted plots. As shown, disturbance constrained the colonization of most nearby species; however, the disturbance may favor the development of species well adapted to the new environmental conditions (Patykowski, 2018; Herben, Klimešová, \& Chytrý, 2018). In our study, the winner species were Alyssum hirsutum, a rare annual species in Romania (Oprea, 2005), and Thymus zygioides, a perennial with vegetative and generative reproduction, also rare in Romania (Oltean et al., 1994). Both species are well represented in the Ponto-Sarmatic steppes of Dobrogea. Analysis of the life span of

Peer) reviewing PDF | (2020:12:56079:1:0:NEW 20 Feb 2021) 
374 protected plants from the two environments showed that the proportion of annual plants was 375 slightly higher in disturbed plots than in disturbed plots (Fig. 5b). Herben, Klimešová \& Chytrý 376 (2018) suggest that annual plants are well adapted to various degrees of disturbance severity and 377 frequency and may flourish in the first stages of disturbance, but over time are replaced by 378 perennials. For example, annual plants might be favored by the anemochory trait, which is the 379 case with Alyssum hirsutum inventoried in 27 plots, and Bombycilaena erecta inventoried in 16

380

381

382

383

384

385

386

387

388

389

390

391

392

393

394

395

396

397

398

399

400

401

402

403

404

405

406

407

408

409

410

411

412

413 plots. In our case, the relatively higher proportion of plants in the disturbed plots may suggest repeated disturbance events during the ten years of the Agighiol wind farm's operational phase. Disturbance can also favor species with particular traits, such as growth on stony substrates (Schnoor \& Olsson, 2010; Kompała-Baba et al., 2019). This is observed in Alyssum caliacrae, a species representative of Dobrogea's stony grasslands (Dihoru \& Negrean, 2009), which found better propagation conditions in disturbed areas and maintained a higher abundance compared with the adjacent undisturbed habitat (Urziceanu et al., 2020).

The dissimilarity of undisturbed and disturbed plots is also evident from the NDSM ordination (Fig. 6) and beta-diversity analysis (Fig. 7). The spatial turnover component of beta-dissimilarity was higher than nestedness-resultant in all compared environments (within undisturbed plots, within disturbed plots, and between undisturbed and disturbed plots) due to the presence of many species restricted to an environment (Baselga \& Laprieur, 2015). Furthermore, the lower nestedness of both environments indicates a significant heterogeneity of disturbed and undisturbed communities, with fewer than expected species in common in each assemblage (e.g., Thymus zygioides, Alyssum hirsutum). The higher turnover and lower nestedness observed for the undisturbed plots can be explained by plot location within Dealurile Agighiolului, specifically by the nearby habitats. Around the towers located on primary steppe grasslands (towers: CC_01, CC_04, CC_05, DP_04, DP_05, DP_06, DP_07, DP_08, DP_09, DP_10, DP_11, and DP_12), we inventoried plants species characteristic for this habitat, such as Adonis vernalis, Allium guttatum, Allium saxatile, Alyssum caliacrae, Campanula romanica, Crocus pallasii, Dianthus nardiformis, Echinops ritro subsp. ruthenicus, Euphorbia myrsinites, Hedysarum grandiflorum subsp. grandiflorum, Hornungia petraea, Koeleria lobata, Minuartia hybrida, Ornithogalum amphibolum, Ornithogalum sigmoideum, Paronychia cephalotes, Salvia nutans, Scutellaria orientalis var. pinnatifida, Seseli rigidum subsp. peucedanifolium, Silene supina, Stachys angustifolia, Sternbergia colchiciflora, Tanacetum millefolium, Trigonella gladiata, Valerianella coronata, and Vincetoxicum fuscatum. In contrast, around the towers located in ruderalized secondary grasslands (towers: CC_02, CC_03, DP_01, and DP_02), we observed fewer species, but also a different set of species (Adonis flammea, Alyssum hirsutum, Bombycilaena erecta, Bupleurum apiculatum, Colchicum triphyllum, Muscari neglectum, and Scorzonera mollis). Ruderalization is due to intensive grazing and agricultural activity, which interfere with the wind energy farm area.

The present study provides data suggesting a clear local-scale impact of wind energy farms on plant species prone to population size reductions and extinction. Plant communities were inventoried annually between 2015 and 2019, thus sufficiently capturing plant communities at 
414 disturbed sites. Despite our approach's robustness, the lack of rigorous surveys before the 415 construction of the wind energy farm (Badea et al., 2012) limits the study to a post hoc one.

416 Thus, some of the differences might be due to initial disturbance and not due to the operational 417 phase. Furthermore, because we focused on a single wind energy complex in an area with many 418 plant communities endemic to Romania, our results may need to be validated in other 419 environments such as wind energy complexes within habitats with more common species.

420

\section{Conclusions}

422 Although the number of wind energy farms within protected areas has significantly increased in

423

424

425

426

427

428

429

430

431

432

433

434

435

436

437

438

439

440

441

442

443

444

445

446

447

448

449

450

451

452 the past decade, few studies have quantified their impact on protected plant species recovery. Our study suggests that wind energy farms' operation affects the local diversity of protected plant species and that disturbed areas have a significantly lower recovery rate in the absence of restoration and post-restoration measures at the technological platforms. The high number of protected species in the undisturbed plots indicates that the plant communities are not affected by construction and operation activities. We conclude that after ten years of operating the Agighiol wind farm, the effects on protected plant communities are present only in areas where the vegetation has been removed, and maintenance activities are carried out regularly. Hence, enforcing conservation activities, such as a narrower area available for maintenance and operation of towers, may allow the expansion of the populations of protected plants and a higher rate of colonization from nearby sources.

\section{Acknowledgments}

We thank the Enel Green Power Romania and the custodian of the Dealurile Agighiolului Natura 2000 protected area for allowing the research activity in the wind energy farm Agighiol. We also thank the two reviewers for their extensive comments and suggestions and Edward F. Rozylowicz for proofreading and suggestions, which helped us improve the manuscript.

\section{References}

Badea G, Roșca V, Cîrnat MJ, Badea G. 2012. Raport de monitorizare a biodiversităţii zonei de implementare a parcurilor eoliene aparținând S.C. Enel Green Power Romania S.R.L. (Valea Nucarilor). Available at shorturl.at/fzDGN (accessed July 2020).

Bandoc G, Prăvălie R. 2015. Climatic water balance dynamics over the last five decades in Romania's most arid region, Dobrogea. Journal of Geographical Sciences 25(11): 1307-1327 DOI: $10.1007 / \mathrm{s} 11442-015-1236-1$.

Baselga A, Leprieur F. 2015. Comparing methods to separate components of beta diversity. Methods in Ecology and Evolution 6:1069-1079. DOI: 10.1111/2041-210x.12388.

Baselga A, Orme D, Villeger S, De Bortoli J, Leprieur F, Logez M, Henriques-Silva R. 2020. betapart: partitioning beta diversity into turnover and nestedness components. Available at https://CRAN. R-project. org/package= betapart (accessed August 2020). 
453 Boşcaiu N, Coldea G, Horeanu C. 1994. Lista roşie a plantelor vasculare dispărute, periclitate, 454 vulnerabile şi rare din flora României. Ocrotirea Naturii și a mediului înconjurător 38(1): 45-56. 455 Brînzan T. 2013. Catalogul habitatelor, speciilor și siturilor Natura 2000 în România. București, 456 România: Ministerul Mediului și Schimbărilor Climatice - Direcția Generală Protecția Naturii. 457 CBD - Convention on Biological Diversity. 2012. The Global Strategy for Plant Conservation: 458 2011-2020. Richmond, UK: Botanic Gardens Conservation International.

459 Chao A, Gotelli NJ, Hsieh TC, Sander EL, Ma KH, Colwell RK, Ellison AM. 2014. Rarefaction 460 and extrapolation with Hill numbers: a framework for sampling and estimation in species 461 diversity studies. Ecological monographs 84(1): 45-67 DOI 10.1890/13-0133.1.

462 Chifu T, Țupu E. 2009. Phytocoenoses specific to the vegetation of Dobrogea. Romanian

463 Journal of Biology - Plant Biology 54: 47-59.

464 Chiu CH, Chao A. 2014. Distance-Based Functional Diversity Measures and Their 465 Decomposition: A Framework Based on Hill Numbers. PLoS ONE 9:e100014. DOI: 466 10.1371/journal.pone.0100014.

467 Corlett RT. 2016. Plant diversity in a changing world: status, trends, and conservation needs.

468 Plant Diversity 38(1): 10-16 DOI 10.1016/j.pld.2016.01.001.

469 Council of the European Communities. 1992. Council Directive 92/43/EEC of 21 May 1992 on

470 the conservation of natural habitats and of wild fauna and flora. Official Journal of the European

471 Communities L206/7. Available at https://eurlex.europa.eu/legal-content/ EN/

472 TXT/?uri=celex:31992L0043 (accessed 24 September 2020).

473 Dargie T. 2004. Windfarm impacts on blanket peat habitats in Scotland. In Maxwell F. ed.

474 Renewable energy - is it ecologically friendly? Proceedings of the 19th Conference of the

475 Institute of Ecology and Environmental Management, London 18 May 2004. IEEM, Winchester, $476 \quad 43-51$.

477 Dihoru G, Dihoru A. 1994. Plante rare, periclitate și endemice în flora României - Lista Roșie.

478 Acta Botanici Horti Bucurestiensis 1993-1994: 173-197.

479 Dihoru G, Negrean G. 2009. Red data book of vascular plants of Romania. București: Editura

480 Academiei Române.

481 Doba A, Nistorescu M, Stănescu S, Papp T, Nagy AA, Măntoiu D. 2016. Ghid de bune practici 482 în vederea planificării și implementării investiţiilor din sectorul Energie Eoliană. Asociaţia 483 Grupul Milvus.

484 Dragomir G, Şerban A, Năstase G, Brezeanu AI. 2016. Wind energy in Romania: A review from 4852009 to 2016. Renewable and Sustainable Energy Reviews 64: 129-143 DOI:

486 10.1016/j.rser.2016.05.080.

487 Fagúndez J. 2008. Effects of wind farm construction and operation on mire and wet heath

488 vegetation in the Monte Maior SCI, North-West Spain. Mires \& Peat 4: 1-12.

489 Fraga MI, Romero-Pedreira D, Souto M, Castro D, Sahuquillo E. 2008. Assessing the impact of 490 wind farms on the plant diversity of blanket bogs in the Xistral Mountains (NW Spain). Mires 491 and Peat 4: 1-10. 
492 Gasparatos A, Doll CN, Esteban M, Ahmed A, Olang TA. 2017. Renewable energy and 493 biodiversity: Implications for transitioning to a Green Economy. Renewable and Sustainable 494 Energy Reviews 70: 161-184 DOI 10.1016/j.rser.2016.08.030.

495 Georgescu MI, Săvulescu E, Dobrescu E, Toma F. 2015. Inventory of Dobrogea Flora-Basic 496 Step in Preserving the Natural Heritage of the Area. Transdisciplinarity and Communicative 497 Action, LUMEN-TCA 2014: 305-310.

498 Guvernul României. 2007. Ordonanţă de urgenţă nr. 57 din 20 iunie 2007 Privind regimul ariilor 499 naturale protejate, conservarea habitatelor naturale, a florei şi faunei sălbatice OUG 57/2007. 500 Monitorul Oficial al României 442: 2-8.

501 Herben T, Klimešová J, Chytrý M. 2018. Effects of disturbance frequency and severity on plant 502 traits: An assessment across a temperate flora. Functional Ecology 32(3): 799-808 DOI:

503 10.1111/1365-2435.13011.

504 Hsieh TC, Ma KH, Chao A. 2016. iNEXT: an R package for rarefaction and extrapolation of 505 species diversity (Hill numbers). Methods in Ecology and Evolution 7(12): 1451-1456 DOI: 506 10.1111/2041-210X.12613.

507 Johnson CN, Balmford A, Brook BW, Buettel JC, Galetti M, Guangchun L, Wilmshurst JM 508 2017. Biodiversity losses and conservation responses in the Anthropocene. Science 356(6335): 509 270-275 DOI 10.17863/CAM.10996.

510 Kassambara A. 2020. ggpubr: ggplot2 based publication ready plots. R package version 0.4.0 511 (2020). Available at hhttps://rpkgs.datanovia.com/ggpubr (accessed August 2020).

512 Katsaprakakis DA. 2012. A review of the environmental and human impacts from wind parks. A 513 case study for the Prefecture of Lasithi, Crete. Renewable and Sustainable Energy Reviews 514 16(5): 2850-2863 DOI: 10.1016/j.rser.2012.02.041.

515 Keehn JE, Feldman CR. 2018. Disturbance affects biotic community composition at desert wind 516 farms. Wildlife Research 45(5): 383-396 DOI: 10.1071/WR17059.

517 Kompała-Bąba A, Bierza W, Błońska A, Sierka E, Magurno F, Chmura D, Besenyei L, Radosz

518 L, Woźniak G. 2019. Vegetation diversity on coal mine spoil heaps-how important is the texture 519 of the soil substrate?. Biologia 74(4): 419-436 DOI: 10.2478/s11756-019-00218-X.

520 Kuvlesky Jr WP, Brennan LA, Morrison ML, Boydston KK, Ballard BM, Bryant FC. 2007.

521 Wind energy development and wildlife conservation: challenges and opportunities. The Journal 522 of Wildlife Management 71(8): 2487-2498 DOI: 10.2193/2007-248.

523 Li D. 2020. hillR: Diversity Through Hill Numbers. v. 0.5. Available at https://cran.r524 project.org/web/packages/hillR (accessed January 2021).

525 Măntoiu DŞ, Kravchenko K, Lehnert LS, Vlaschenko A, Moldovan OT, Mirea IC, Stanciu RC, 526 Zaharia R, Popescu-Mirceni R, Nistorescu MC, Voigt CC. 2020. Wildlife and infrastructure: 527 impact of wind turbines on bats in the Black Sea coast region. European Journal of Wildlife 528 Research 66(3): 1-13 DOI: 10.1007/s10344-020-01378-x.

529 Meng HH, Zhou SS, Li L, Tan YH, Li JW, Li J. 2019. Conflict between biodiversity 530 conservation and economic growth: insight into rare plants in tropical China. Biodiversity and 531 conservation 28(2): 523-537 DOI: 10.1007/s10531-018-1661-4. 
532 Ministerul Mediului, Apelor şi Pădurilor. 2016. Ordinul Ministrului Mediului, Apelor și 533 Pădurilor nr. 948/2016 privind aprobarea Planului de management și a Regulamentului sitului

534 Natura 2000 ROSCI0060 Dealurile Agighiolului și al ariei naturale protejate Agighiol-Nucarilor, 535 cod 2.771., Monitorul Oficial, 515, București. Available at shorturl.at/blqLT (accessed 10

536 September 2020).

537 Miu IV, Chişamera GB, Popescu VD, Iosif R, Nita A, Manolache S, Gavril VD, Cobzaru I, 538 Rozylowicz L. 2018. Conservation priorities for terrestrial mammals in Dobrogea Region, 539 Romania. ZooKeys 792(3): 133-158 DOI: 10.3897/zookeys.792.25314.

540 Miu IV, Rozylowicz L, Popescu VD, Anastasiu P. 2020. Identification of areas of very high

541 biodiversity value to achieve the EU Biodiversity Strategy for 2030 key commitments. PeerJ 8:

542 e10067 DOI: 10.1101/2020.07.14.202341.

543 Mouillot D, Bellwood DR, Baraloto C, Chave J, Galzin R, Harmelin-Vivien M, Kulbicki M,

544 Lavergne S, Lavorel S, Mouquet N, Paine CET, Renaud J, Thuiller W. 2013. Rare species

545 support vulnerable functions in high-diversity ecosystems. PLoS Biology 11(5): e1001569 DOI:

$546 \quad 10.1371$ journal.pbio.1001569.

547 Natural England. 2010. Commissioned Report, Investigating the impacts of windfarm

548 development on peatlands in England: Part 2 Appendices and References. Available at

549 http://publications.naturalengland.org.uk/publication/43010 (accessed 5 September 2020).

550 Nita A, Butler A, Rozylowicz L, Patru-Stupariu I. 2015. Perception and use of landscape

551 concepts in the procedure of Environmental Impact Assessment: Case study - Switzerland and

552 Romania. Land Use Policy 44:145-152 DOI: 10.1016/j.landusepol.2014.12.006

553 Nita A. (2019) Empowering impact assessments knowledge and international research

554 collaboration - a bibliometric analysis of Environmental Impact Assessment Review journal.

555 Environmental Impact Assessment Review 78:106283 DOI: 10.1016/j.eiar.2019.106283

556 Oksanen J, Blanchet FG, Kindt R Legendre P, Minchin PR, O'Hara RB, Simpson GL, Solymos

557 P, Stevens MHH, Wagner H. 2019. Package 'vegan'. Community ecology package, version 2.5-6, 558 pp.1-296.

559 Oltean M Negrean G. Popescu A., Roman N, Dihoru G, Sanda V, Mihăilescu S. 1994. Lista roșie 560 a plantelor superioare din România. Studii, sinteze, documentații de ecologie 1: 1-52.

561 Oprea A. 2005. Lista critică a plantelor vasculare din România. Iași: Edit. Universității A.I.

562 Cuza.

563 Passos I, Silva M, Mesquita S, Marques AT, Bernardino J, Mascarenhas M. 2013. Aliens in wind 564 farms - Preventing and monitoring impacts on vegetation. [Abstract]. Conference on Wind

565 Energy and Wildlife Impacts, Naturvårdsverket Rapport 6546: 80.

566 Pătru-Stupariu I, Calotă AM, Santonja M, Anastasiu P, Stoicescu I, Biriş I, Stupariu M-S, Buttler

567 A. 2019. Do wind turbines impact plant community properties in mountain region? Biologia 568 74(12): 1613-1619 DOI: 10.2478/s11756-019-00333-9.

569 Patykowski JW. 2018. The effect of disturbance on plant rarity and ecosystem function. Ph. D. 570 Thesis, Deakin University. 
571 Petrescu M. 2007. Dobrogea and the Danube Delta: flora and habitat conservation. Tulcea:

572 Eco-Museal Research Institute.

573 Petrescu M. 2016. Preliminary Data Concerning the Conservation Value of the Natural Habitats

574 and Their Correspondent Threats within Tulcea County - Romania. Studii și cercetări de

575 științele naturii și mezeologie Delta Dunării 6: 43-54.

576 Petrescu M. 2018. Contribuții la cunoașterea florei și habitatelor din situl de importanță

577 comunitară Dealurile Agighiolului, județul Tulcea. Studii și cercetări de științele naturii și

578 mezeologie Delta Dunării 7: 83-94.

579 R Core Team (2020). R: A language and environment for statistical computing. R Foundation for

580 Statistical Computing, Vienna, Austria. URL http://www.R-project.org/.

581 Renou-Wilson F, Farrell CA. 2009. Peatland vulnerability to energy-related developments from

582 climate change policy in Ireland: the case of wind farms. Mires and Peat 4(8): 1-11.

583 Rey V, Ianos I, Groza O, Patroescu M. 2007. Atlas de la Roumanie (Nouvelle edition).

584 Montpellier: Reclus.

585 Rozylowicz L, Nita A, Manolache S, Popescu VD, Hartel T. 2019. Navigating protected areas

586 networks for improving diffusion of conservation practices. Journal of Environmental

587 Management 230: 413-421 DOI: 10.1016/j.jenvman.2018.09.088.

588 Sanda V, Arcuș M. 1999. Sintaxonomia grupărilor vegetale din Dobrogea și Delta Dunării.

589 Pitești: Edit. Cultura.

590 Sârbu A, Negrean G, Pascale G, Anastasiu P. 2006. Globally and European threatened plants

591 present in Dobrogea (South-Eastern Romania). Nature Conservation: 116-122 DOI:

592 10.1007/978-3-540-47229-2_13.

593 Sârbu A, Sârbu I, Oprea A, Negrean G, Cristea V, Coldea G, Cristurean I, Popescu G, Oroian S,

594 Tănase C, Bartok K, Gafta D, Anastasiu P, Crişan F, Costache I, Goia I, Maruşca T, Oţel V,

595 Sămărghiţan M, Henţea S, Pascale G, Răduţoiu D, Baz A, Boruz V, Puşcaş M, Hiriţiu M, Stan I,

596 Frink J. 2007. Arii speciale pentru protecţia şi conservarea plantelor în România. Important

597 Plant Areas (IPA-s) in Romania. Bucureşti: Edit. Victor B Victor.

598 Sârbu I, Ștefan N, Oprea A. 2013. Plante vasculare din România. Determinator ilustrat de teren.

599 Bucureşti: Victor B Victor.

600 Schnoor TK, Olsson PA. 2010. Effects of soil disturbance on plant diversity of calcareous

601 grasslands. Agriculture, ecosystems \& environment 139(4):714-719 DOI:

602 10.1016/j.agee.2010.10.018.

603 Schulze K, Knights K, Coad L, Geldmann J, Leverington F, Eassom A, Marr M, Butchart SHM,

604 Hockings F, Burgess ND. 2018. An assessment of threats to terrestrial protected areas.

605 Conservation Letters 11(3): e12435 DOI: 10.1111/conl.12435.

606 Silva MR, Passos I. 2017. Vegetation. In Perrow M.R ed. Wildlife and Wind Farms, Conflicts

607 and Solutions, Vol. 1 Onshore: Potential Effects. Exeter, UK: Pelagic Publishing, 40-62.

608 Tang B, Wu D, Zhao X, Zhou T, Zhao W, Wei H. 2017. The observed impacts of wind farms on

609 local vegetation growth in northern China. Remote Sensing 9(4): 1-12 DOI: 10.3390/rs9040332. 
610 Țupu E. 2009. Cercetări floristice și fitocenologice în Dealurile Tulcei. PhD Thesis, University

611 Alexandru Ioan Cuza, Faculty of Biology, Iaşi.

612 Țupu E. 2010. Contributions on chorology of rare plant species from Tulcea Hills (Romania).

613 Acta Horti Botanici Bucurestiensis 37: 37-43.

614 Urziceanu M, Anastasiu P, SSesan TE. 2020. Rare and threatened plants in the area of the wind

615 farm located in Natura 2000 site ROSCI0060 Dealurile Agighiolului (Romania). Acta Horti

616 Botanici Bucurestiensis 46: 5-33.

617 Xu K, He L, Hu H, Liu S, Du Y, Wang Z, Li Y, Li L, Khan A, Wang G. 2019. Positive

618 ecological effects of wind farms on vegetation in China's Gobi desert. Scientific reports 9(1): 1619 11 DOI:10.1038/s41598-019-42569-0.

620 Zambrano J, Garzon-Lopez CX, Yeager L, Fortunel C, Cordeiro NJ, Beckman NG. 2019. The

621 effects of habitat loss and fragmentation on plant functional traits and functional diversity: what 622 do we know so far? Oecologia, 191(3): 505-518 DOI: 10.1007/s00442-019-04505-x

623 Zar JH. 2010. Biostatistical analysis. (5th edn), Pearson Prentice-Hall: Upper Saddle River, NJ.

624 Zhou L, Tian Y, Roy SB, Thorncroft C, Bosart LF, Hu Y. 2012. Impacts of wind farms on land

625 surface temperature. Nature Climate Change 2(7): 539-543 DOI: 10.1038/nclimate1505. 


\section{Table 1 (on next page)}

Habitats of community interest around the wind turbines located in Dealurile Agighiolului Natura 2000 site 


\begin{tabular}{|l|l|}
\hline Wind energy turbines & Habitats \\
\hline CC_01, CC_05, DP_05, & 62C0* Ponto-Sarmatic steppes represented by primary steppe \\
DP_06, DP_07, DP_08, & grasslands with floristic elements characteristics of the association \\
DP_09, DP_10, DP_11, & Koeleria lobata - Thymetum zygioidi, such as Thymus zygioides, \\
DP_12 & $\begin{array}{l}\text { Agropyron ponticum, Allium rotundum, Koeleria lobata, Festuca } \\
\text { valesiaca. }\end{array}$ \\
\hline CC_04, DP_04 & $\begin{array}{l}\text { 62C0* Ponto-Sarmatic steppes represented by primary steppe } \\
\text { grasslands with floristic elements characteristics of the association } \\
\text { Koeleria lobata }- \text { Thymetum zygioidi and elements of the association } \\
\text { Paeonio peregrinae - Carpinetum orientalis that is characteristic of } \\
\text { habitat 91AA* Eastern white oak woods. }\end{array}$ \\
\hline CC_02, CC_03, DP_01, \\
DP_02 & $\begin{array}{l}\text { 62C0* Ponto-Sarmatic steppes represented by secondary grasslands } \\
\text { with floristic elements of the associations Artemisio austriacae - } \\
\text { Poëtum bulbosae and Taraxaco serotini-Bothriochloëtum ischaemi: } \\
\text { Taraxacum serotinum, Artemisia austriaca, Bothriochloa } \\
\text { ischaemum, Cynodon dactylon, Bromus commutatus, Bromus } \\
\text { hordeaceus, Daucus carota subsp. carota, Marrubium peregrinum. }\end{array}$ \\
\hline DP_03 & $\begin{array}{l}\text { 91AA* Eastern white oak woods represented by the association } \\
\text { Paeonio peregrinae - Carpinetum orientalis. }\end{array}$ \\
\hline
\end{tabular}


Figure 1

Location of Agighiol wind energy farm within Dealurile Agighiolului Natura 2000 site. There are 17 wind towers, 12 on Pietros Hill (DP_01 to DP_012) and 5 on Caraconstantin Hill (CC_01 to CC_05).

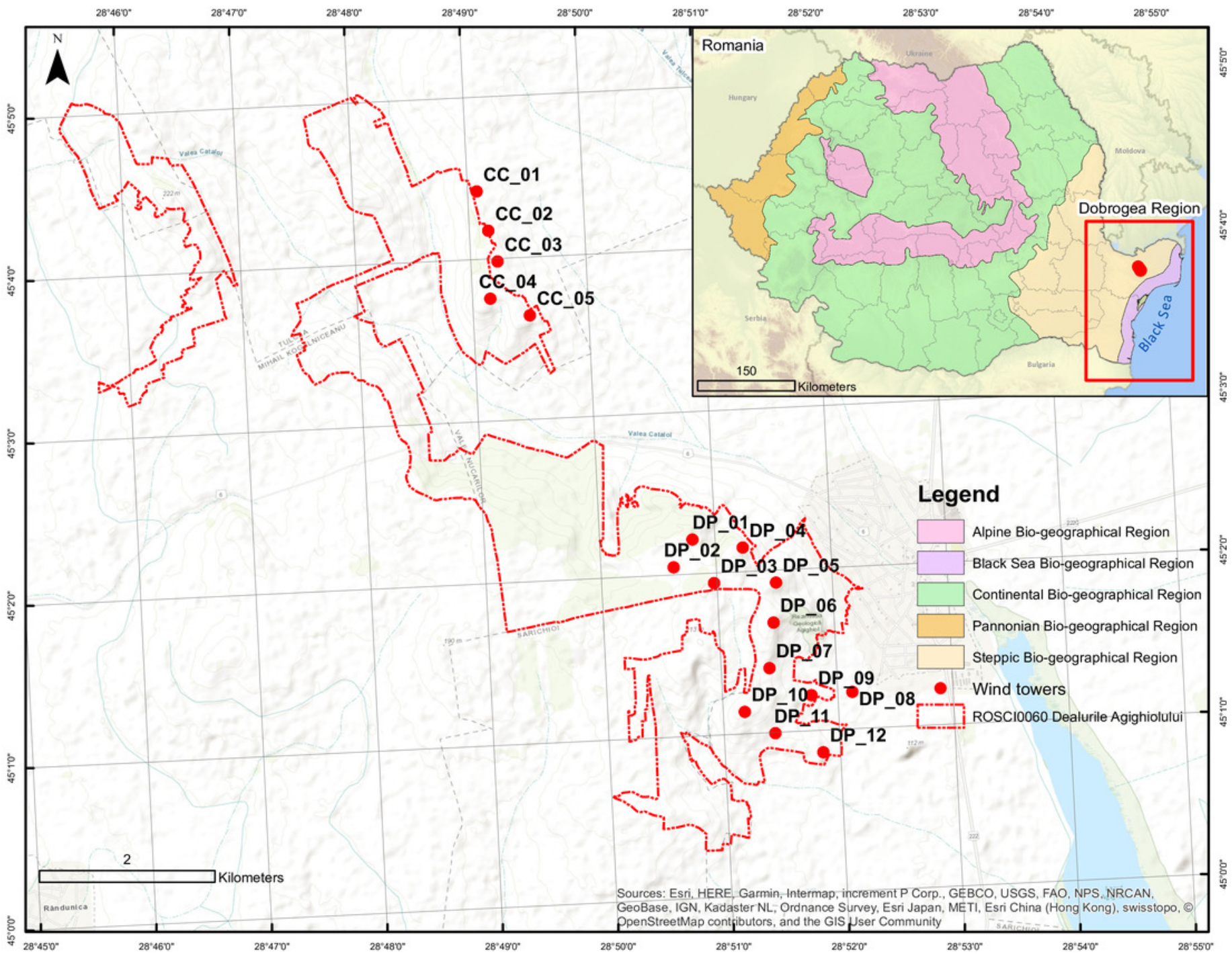


Figure 2

Pairwise comparison of observed species richness in undisturbed and disturbed plots from Agighiol wind energy farm.

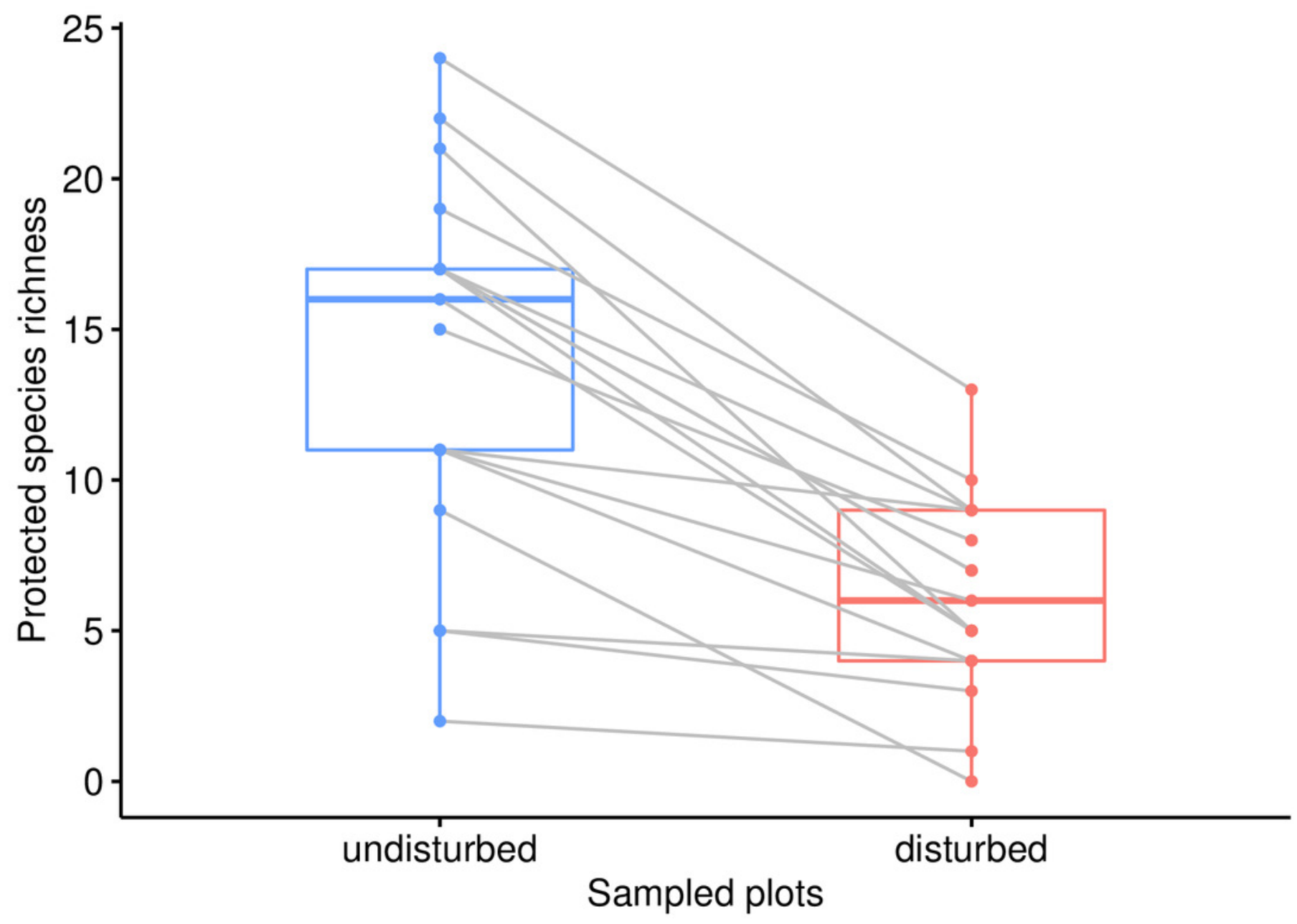


Figure 3

Sample-size-based rarefaction and extrapolation with Hill numbers parametrized by species diversity in undisturbed, disturbed and all surveyed plots from Agighiol wind energy farm.

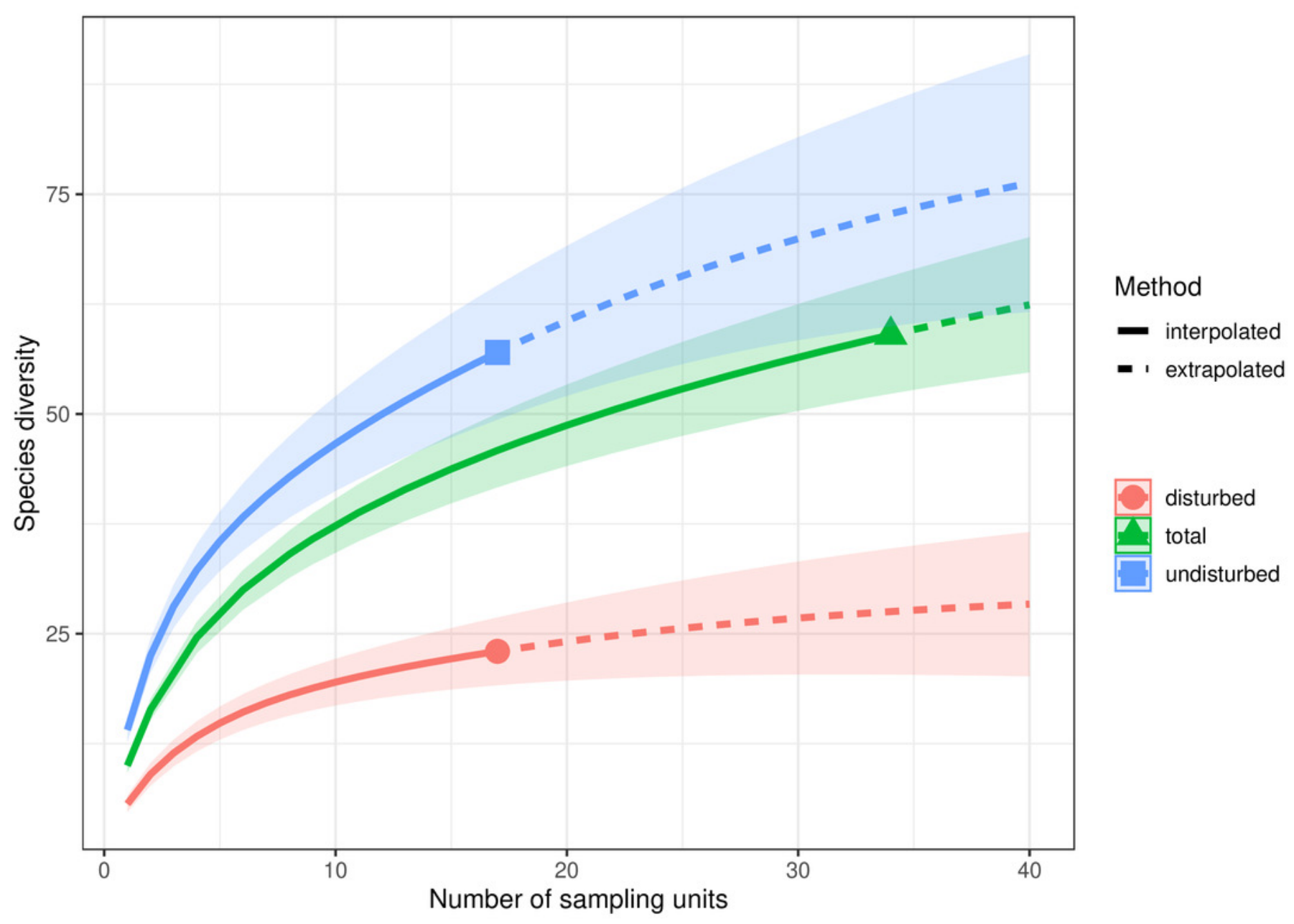


Figure 4

Frequency of rare, endemic and threatened plant species within undisturbed and disturbed plots from Agighiol wind energy farm.

(A) Species names are provided for first 10 taxa as incidence in disturbed and undisturbed plots; (B) $\mathrm{Ch}=$ Chamaephyte, $\mathrm{G}=$ Geophyte, $\mathrm{H}=$ Hemicryptophyte, $T h=$ Therophyte.

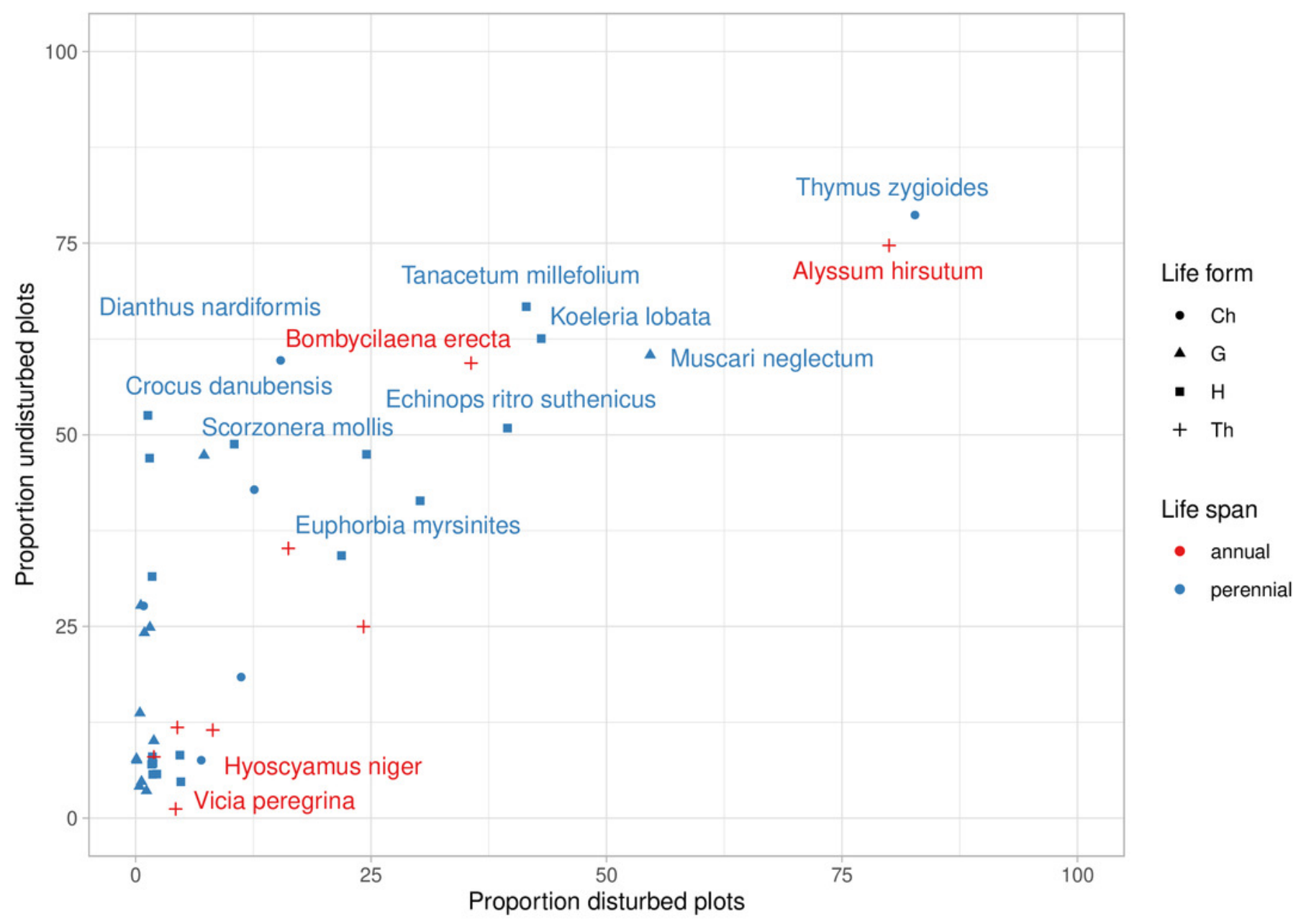




\section{Figure 5}

Proportion of traits for rare, endemic and threatened plant species within undisturbed and disturbed plots from Agighiol wind energy farm.

a) Life form; b) Life span; c) Vegetative reproduction; d) Seed dispersal.
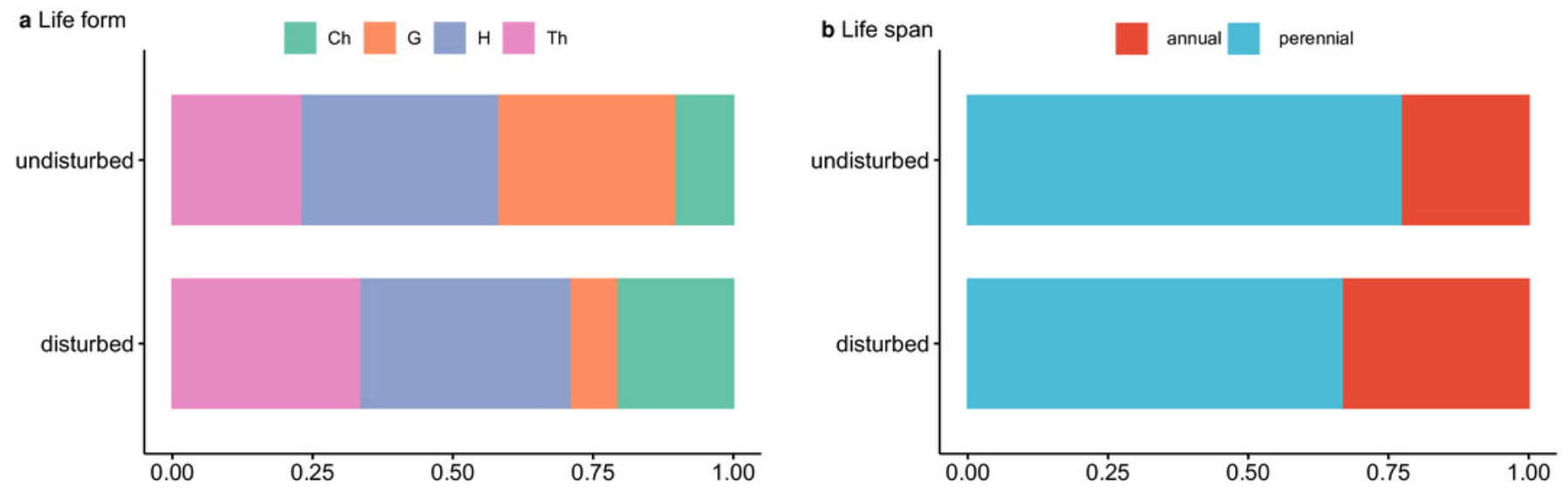

c Vegetative reproduction

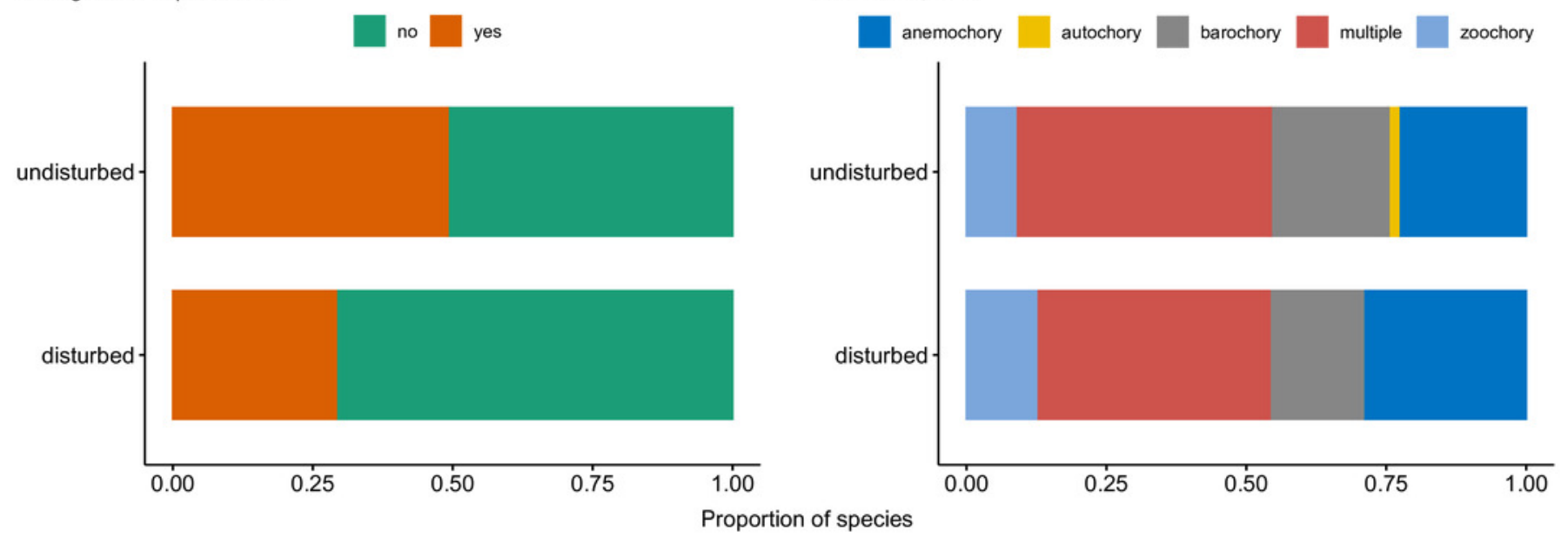

d Seed dispersal 
Figure 6

The NMDS ordination plot showing the differentiation of disturbed and undisturbed protected plant species communities from Agighiol wind energy farm.

Numbers in colors $=$ sites, $\mathrm{SP}=$ species; blue $=$ undisturbed sites, red $=$ disturbed sites, IDs of species and sites are in Data S1.

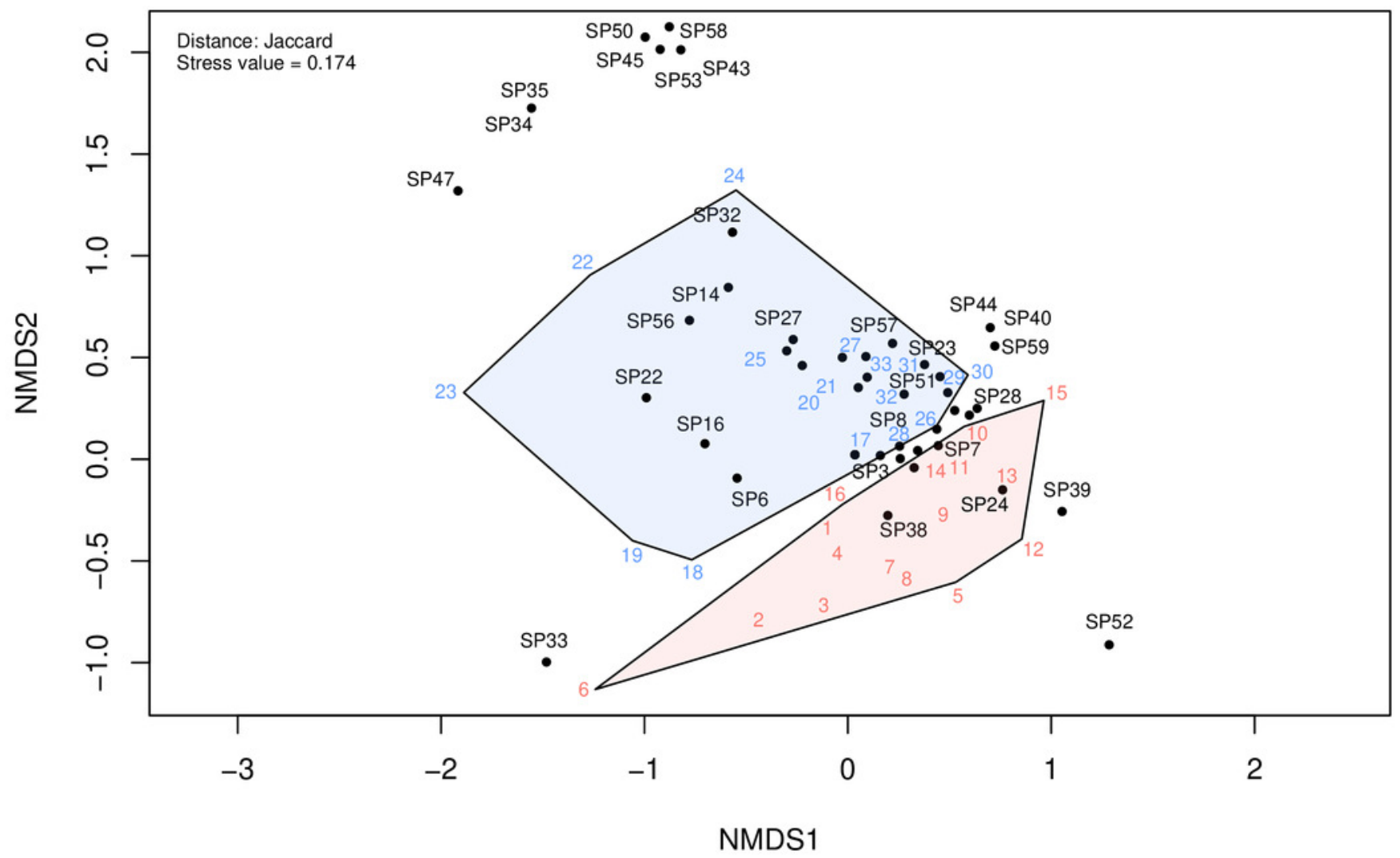


Figure 7

Beta-diversity expressed as Jaccard dissimilarity in disturbed, undisturbed, and all plots from Agighiol wind energy farm.

a) Total beta dissimilarity; b) Spatial turnover dissimilarity; c) nestedness-resultant dissimilarity.
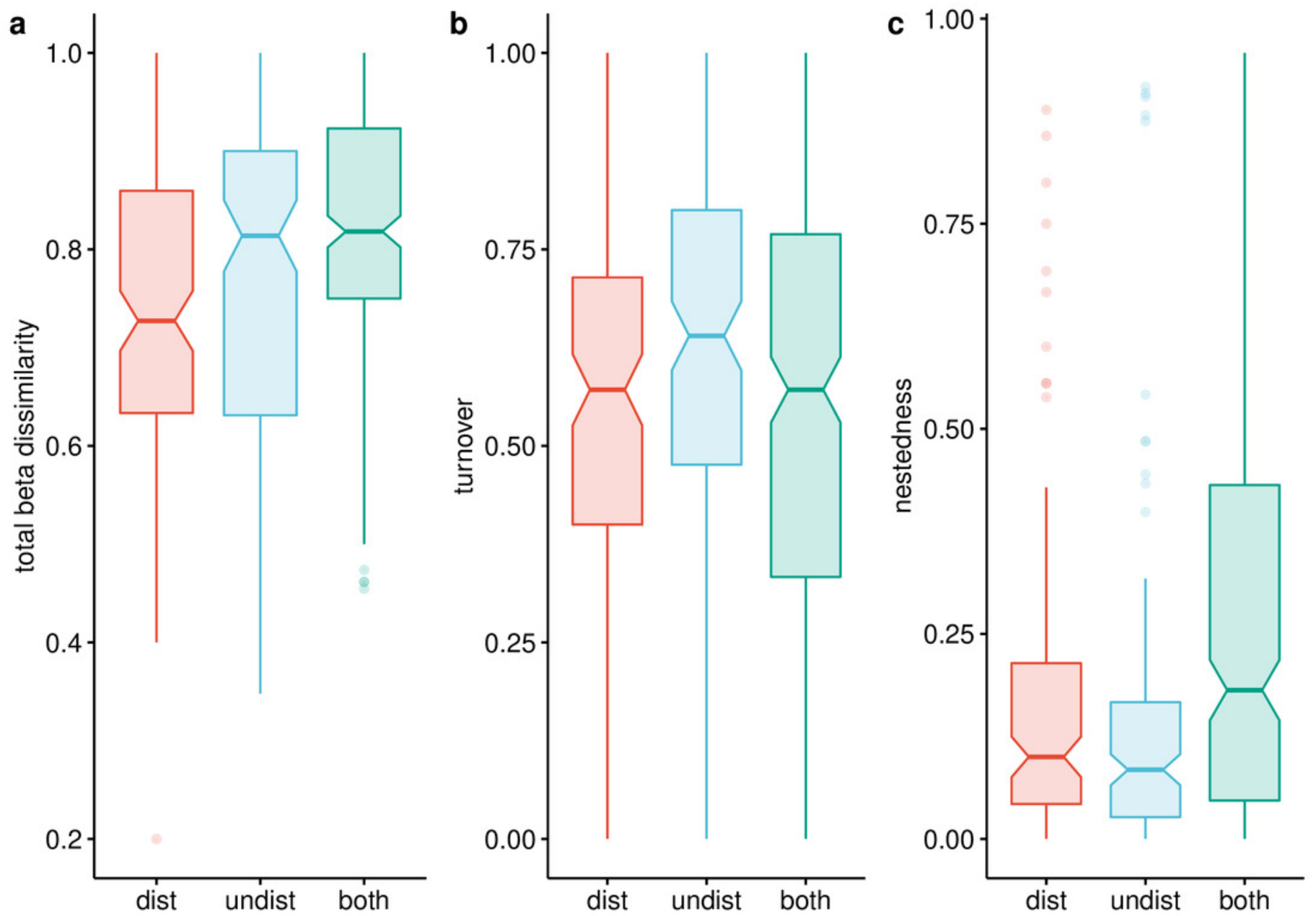